\title{
A tolerância à corrupção no Brasil: uma antinomia entre normas morais e prática social.
}

\author{
Fernando Filgueiras \\ Departamento de Ciência Política \\ Universidade Federal de Minas Gerais
}

\begin{abstract}
Resumo: Este artigo aborda o tema da corrupção no Brasil e trata da antinomia existente, no âmbito da opinião pública brasileira, entre normas morais, que regulam os significados políticos da corrupção, e prática cotidiana na esfera pública. O artigo aborda o conceito de corrupção e o modo como ele é construído no Brasil, além de construir uma perspectiva teórica balizada em análise empírica. Está baseado nos resultados do survey sobre corrupção, realizado no ano de 2008.
\end{abstract}

Palavras-chave: corrupção, democracia, moralidade, práticas sociais

Abstract: This article addresses the issue of corruption in Brazil and comes from the contradiction, existing within the Brazilian public opinion, between moral obligations and the meanings of political corruption. The article discusses the concept of corruption and how it is built in Brazil, and also builds a theoretical perspective on corruption through empirical analysis. It is based on the results of the survey on corruption, conducted in year 2008.

Keywords: corruption, democracy, morality, social practices 


\section{Introdução}

Quando se abre o jornal, no Brasil, é raro não nos defrontarmos com escândalos no mundo político. Casos de malversação de recursos públicos, uso indevido da máquina administrativa, redes de clientelas e tantas outras mazelas configuram uma sensação de mal-estar coletivo, em que sempre olhamos de modo muito cético os rumos que a política, no Brasil, tem tomado. Criam-se, dessa forma, um clamor moral e um clima de caça às bruxas que geram instabilidade $\mathrm{e}$ um muro de lamentações e barreiras a projetos de políticas públicas. Contudo, apesar dessa sucessão de escândalos no Brasil, existe uma sensação de impotência por parte da sociedade; a corrupção é tolerada e os cidadãos ficam apenas aguardando qual será o próximo escândalo que circulará nos jornais.

Essa sensação de mal-estar coletivo com a corrupção cria concepções de senso comum acerca de uma natural desonestidade do brasileiro. Um dos traços característicos do senso comum no Brasil é que o brasileiro típico tem um caráter duvidoso e que, a princípio, não se nega a levar algum tipo de vantagem no âmbito das relações sociais ordinárias. Por isso, vários indicadores de confiança apontam o Brasil como um país onde a desconfiança impera. Para além do senso comum, esse tipo de leitura da realidade social brasileira converge para termos centrais das interpretações do país e a produção de conceitos no mundo acadêmico também incorpora esse tipo de visão, sendo o brasileiro típico um cidadão voltado para seus desejos agonísticos, que se expressam em formas sociais tais como o jeitinho e a malandragem.

Culpa-se, sobremaneira, nossa herança histórica deixada pelo mundo ibérico, que teria feito com que o Brasil não conhecesse o processo de racionalização típico do Ocidente e incorporasse, os valores e princípios do mundo protestante, ascético e voltado para uma ética dos deveres e do trabalho. O projeto de interpretação do Brasil fornecido pela vertente do patrimonialismo tende a tomar esse pressuposto como característica antropológica, alicerçado em uma visão muitas vezes derivada de outras experiências sociais. Afinal, a herança do patrimonialismo ibérico deixou algumas mazelas na constituição da sociedade brasileira, o que acarretaria, sempre, projetos de ruptura com o passado.

Este artigo analisa o problema da corrupção no Brasil a partir da antinomia entre normas morais e prática social, defendendo a hipótese de que a prática de corrupção não está relacionada a aspectos do caráter do brasileiro, mas à constituição de normas informais que institucionalizam certas práticas tidas como moralmente degradantes, mas cotidianamente toleradas. A antinomia entre normas morais e prática social da corrupção no Brasil revela uma outra antinomia: a corrupção é explicada, no plano da sociedade brasileira, pelo fosso que separa os 
aspectos morais e valorativos da vida e a cultura política. Isso acarreta uma tolerância à corrupção que está na base da vida democrática pós-1985.

Na primeira seção do artigo, apresentamos o lugar da corrupção nos projetos de interpretação do Brasil. Na segunda seção, discutimos o conceito de corrupção e os diferentes marcos metodológicos para seu estudo. Na terceira seção, tratamos de uma perspectiva analítica alternativa, na dimensão da cultura política. Na quarta seção do artigo, tratamos da análise empírica da corrupção.

\section{O lugar da corrupção no Brasil}

Não há, no âmbito do pensamento social e político brasileiro, uma teoria da corrupção no Brasil. Pode-se dizer, grosso modo, que esse tema foi deixado de lado nas reflexões acadêmicas e teóricas sobre o Brasil, não havendo, nesse sentido, uma abordagem que dê conta do problema da corrupção no âmbito da política, da economia, da sociedade e da cultura de forma abrangente. Os estudos sobre corrupção no Brasil são recentes, realizados a partir de abordagens comparativas e institucionalistas, sem a pretensão de uma teoria geral, de cunho interpretativo.

Todavia, quando nos deparamos com o tema da corrupção, há, comumente, uma vertente interpretativa do pensamento político e social brasileiro que é mobilizada para explicar os casos de malversação de recursos públicos e uma suposta imoralidade do brasileiro. O problema do patrimonialismo é comumente mobilizado para descrever a corrupção, tendo em vista a cultura política, a economia, a política e a sociedade, de acordo com o problema da modernização, do surgimento das modernas burocracias e da legitimação da política moderna. A incorporação do conceito weberiano de patrimonialismo, no âmbito de algumas interpretações do Brasil, normalmente é o foco analítico para o problema da corrupção, o qual recortaremos a fim de compreender o modo como o conceito de corrupção é construído no contexto das disputas intelectuais do pensamento social e político brasileiro.

Supõe-se que a tradição política brasileira não respeita a separação entre o público e o privado, não sendo, o caso brasileiro, um exemplo de Estado moderno legitimado por normas impessoais e racionais. O patrimonialismo é a mazela da construção da República, de maneira que ele não promoveria a separação entre os meios de administração e os funcionários e governantes, fazendo com que esses tenham acesso privilegiado para a exploração de suas posições e cargos. Dado o patrimonialismo inerente à construção da cena pública brasileira, a corrupção é um tipo de prática cotidiana, chegando mesmo a ser legitimada e explícita no âmbito de uma tradição estamental e tradicional herdada do mundo ibérico.

O patrimonialismo, nosso vício de origem, é fruto de um Estado que intervém na sociedade e coordena e comanda, pelo alto, a exploração do mundo produtivo e 
mercantil. Tal vício de origem é nossa herança do mundo ibérico (FAORO, 2000). De acordo com Faoro, a sociedade ibérica subordinou-se ao Estado, de modo que em Portugal formou-se um absolutismo precoce, que alojou os estamentos da sociedade nos órgãos da burocracia. O estamento burocrático do mundo ibérico comportava-se como proprietário da soberania, criando um sistema de exploração e dominação que se reproduziu como marca fundamental de nossa tradição política por meio de uma corrupção sistêmica ${ }^{1}$.

Ainda segundo Faoro, o patrimonialismo no Brasil é o resultado de uma relação entre Estado e sociedade em que o primeiro oprime a segunda pela reprodução de um sistema de privilégios e prebendas, destinadas aos estamentos alojados na burocracia estatal. Esse estamento burocrático coordena e administra o Estado sem conhecer regras impessoais e racionais, que separem os meios de administração e a função burocrática propriamente dita. O resultado do patrimonialismo é que a corrupção faz parte de um cotidiano de nossa constituição histórica. O clientelismo, a patronagem, o patriarcalismo e o nepotismo constituem tipos de relação do Estado com a sociedade em que a corrupção é a marca fundamental; afinal, à sociedade nada resta senão buscar o acesso aos privilégios do estamento burocrático mediante a compra de cargos públicos e títulos de honraria, favores da burocracia e a participação no erário do Estado. O conceito de patrimonialismo tem uma rigidez histórica que caracteriza um elemento estrutural da sociedade brasileira. Dessa forma, a corrupção é fruto da herança deixada pelos colonizadores portugueses, que confere ao Brasil um forte caráter de sociedade tradicional, onde a corrupção é prática corriqueira em função da ausência de capitalismo, em particular do mercado. Como destaca Faoro:

Tudo acabaria - mesmo alterado o modo de concessão do comércio - em grossa corrupção, com o proveito do luxo, que uma geração malbaratara, legando à estirpe a miséria e o fumo fidalgo, avesso ao trabalho. A corte, povoada de senhores e embaixadores, torna-se o sítio preferido dos comerciantes, todos, porém, acotovelados com a chusma dos pretendentes - pretendentes de mercês econômicas, de cargos, capitanias e postos militares. (...) A expressão completa desta comédia se revela numa arte, cultivada às escondidas: a arte de furtar. A nota de crítica e de censura flui

\footnotetext{
1 A vertente do patrimonialismo, no âmbito do pensamento social e político brasileiro, é derivada de Os donos do poder, de Raymundo Faoro. De acordo com essa vertente, formou-se, no Brasil, um Estado centralizador e expropriador da riqueza, que estaria assentado na existência de um estamento que se alojou na burocracia estatal, de modo a construir todo um sistema de privilégios. Como destaca Campante, o conceito de patrimonialismo em Faoro dista do conceito original, presente na obra de Weber. De acordo com Campante, em Weber, o conceito de patrimonialismo é um princípio de legitimação, baseado em um mundo tradicional, em que, nem sempre, o Estado é centralizado, como, por exemplo, no sistema feudal. A recepção do conceito de patrimonialismo em Faoro, nesse sentido, obedece a uma ampla confusão conceitual e metodológica. A esse respeito, conferir Campante (2003).
} 
de duas direções, ao caracterizar o enriquecimento no cargo como atividade ilícita: a ética medieval, adversa à cobiça, e a ética burguesa, timidamente empenhada em entregar o comércio ao comerciante (FAORO, 2000. p. 99-100).

$\mathrm{Na}$ linhagem do pensamento político brasileiro derivada de Faoro, o patrimonialismo é um problema típico do Estado, conforme uma rigidez estrutural na sociedade brasileira (CARVALHO, 1997). A herança deixada na organização do Estado e da atividade econômica por Portugal explica a corrupção do presente. A partir desse conceito de patrimonialismo a corrupção no Brasil é resultado da constituição histórica do Estado e da sobreposição do estamento burocrático à sociedade. Acreditamos, por outro lado, que a corrupção não pode ser explicada, hoje, pelo conceito de patrimonialismo de Faoro, porque não há, no Brasil, um sistema de legitimação tradicional e as práticas de corrupção não são apenas derivadas do poder estatal, mas têm, também, uma ressonância na cultura política.

Sérgio Buarque de Hollanda ressalta que o problema do patrimonialismo não se resume ao Estado, mas é, também, um problema societal. De acordo com Hollanda, o patrimonialismo é o resultado de uma cultura da personalidade, na qual não existem regras impessoais de relação no plano da sociedade e entre a sociedade e o Estado. No Brasil imperaria “(...) certa incapacidade, que se diria congênita, de fazer prevalecer qualquer forma de ordenação impessoal e mecânica sobre as relações de caráter orgânico e comunal, como o são as que se fundam no parentesco, na vizinhaça e na amizade" (HOLLANDA, 1995, p.137). Essa seria a herança deixada pelo mundo ibérico e sua cultura da cordialidade, marcadas pela inaptidão do brasileiro para construir uma ordem pública e também uma democracia ${ }^{2}$. O problema dessa abordagem é reconhecer que a cultura política brasileira assenta-se apenas no mundo dos sentimentos, sem reconhecer um traço de modernidade e racionalização da sociedade. Esse tipo de leitura empobrece a análise e engessa a possibilidade de mudança social. Além disso, enquadra a explicação da corrupção à formação do caráter do brasileiro e sua natural desonestidade, com o risco de naturalizar a corrupção a partir da existência da família patriarcal, como expressa Hollanda:

\footnotetext{
${ }^{2}$ Não é ponto pacífico nas interpretações do Brasil a vinculação de Sérgio Buarque de Hollanda à vertente do patrimonialismo. Essa vinculação surge a partir da interpretação de Raízes do Brasil feita por Antônio Cândido, que vinculou as leituras do autor em relação à obra de Weber a partir do conceito de patrimonialismo. Hollanda tratava, na verdade, do conceito de patriarcalismo, que está centrado mais na existência de uma privatização do poder, na dimensão da família patriarcal, do que propriamente na existência do Estado ou de qualquer tipo de legitimação. A esse respeito, confrontar Cândido (1995).
} 
Não era fácil aos detentores das posições públicas de responsabilidade, formados por tal ambiente [organização patriarcal de sociedade], compreenderem a distinção fundamental entre público e privado. Assim, eles se caracterizam justamente pelo que separa o funcionário "patrimonial" do puro burocrata conforme a definição de Max Weber. Para o funcionário "patrimonial", a própria gestão pública apresenta-se como assunto de seu interesse particular; as funções, os empregos e os benefícios que deles aufere relacionam-se a direitos pessoais do funcionário e não a interesses objetivos, como sucede no verdadeiro Estado burocrático, em que prevalecem a especialização das funções e o esforço para se assegurarem garantias jurídicas aos cidadãos. (...) Falta a tudo a ordenação impessoal que caracteriza a vida no Estado burocrático (HOLLANDA, 1995, p. 145-146).

O patrimonialismo é o inimigo privilegiado do pensamento social e político brasileiro, de forma que todos os projetos de modernização do Estado, da economia e da sociedade passam pela ideia de ruptura com nosso passado ibérico e afirmação de um modelo de organização estatal moderna, pautado pela impessoalidade e pela racionalidade na relação entre Estado e sociedade (VIANNA, 1999). A ruptura com o passado significa a afirmação de um modelo weberiano de Estado, fundamentado em uma concepção modernizante capaz de fazer submergir nossos vícios de origem, balizados no patrimonialismo.

Ao longo do século XX, o Brasil assumiu uma postura modernizadora, centrada na busca dos elementos de racionalização e transformação cultural, capazes de balizar um projeto de formação da ordem pública conforme os ditames do capitalismo e do desenvolvimento político. De um lado, seria possível afirmar que essa ruptura jamais se processou no caso brasileiro, já que o patrimonialismo no Brasil não teria o mesmo matiz do conceito de patrimonialismo presente em Weber. O patrimonialismo brasileiro passou a olhar para o futuro, assumindo um projeto modernizante que o ocultasse, não se legitimando, dessa forma, pelo passado (SCHWARTZMAN, 1982). Por outro lado, o projeto modernizador no Brasil teria no Estado seu elemento de concretização, à medida que se consolidasse a separação entre os meios de administração e o exercício de cargos e funções governamentais. O Estado, dessa forma, assumiu, acima da sociedade, o papel de sujeito republicano, capaz de criar uma ordem pública e um projeto de democracia que passasse pela transformação da sociedade (VIANNA, 1999). Isso acarretou o fato de vincularmos, historicamente, o problema da corrupção a uma visão estatal, em que a correção das delinquências do homem público brasileiro passaria pela mudança da máquina administrativa, e não dos valores e práticas presentes na sociedade. 
Dessa maneira, a partir dos anos 1930, tendo em vista esse projeto modernizador conduzido pelo Estado, o tema da administração e da gestão pública tornou-se central. A partir desse momento, produziu-se, no Brasil, uma série de reformas no aparato administrativo do Estado, tendo como finalidade a implosão de nosso passado patrimonialista, a afirmação de uma racionalidade típica do Ocidente e o fim da corrupção como prática cotidiana e corriqueira ${ }^{3}$. A corrupção, como um problema do Estado brasileiro, seria combatida se a ruptura com o passado patrimonialista e estamental da administração pública se concretizasse mediante a modernização da máquina administrativa.

Esse projeto de ruptura com o passado quer renegar nossa história a um segundo plano, direcionando o olhar a um porvir colocado nos horizontes de interpretação do Brasil. Sendo o patrimonialismo um problema estatal (FAORO, 2000) e societal (HOLLANDA, 1995), nossos vícios de origem - a corrupção em particular - são explicados por um traço distintivo de caráter do brasileiro, que estaria relacionado a uma história de parasitismo social explícito, tendo em vista uma sociedade estamental e patriarcal, pouco afeita ao capitalismo e ao mundo dos interesses. Uma outra via de abordagem da corrupção no Brasil seria considerar os aspectos da cultura política, tomando uma condição antropológica do brasileiro e pela análise de seu caráter.

Esse traço de caráter propenso à corrupção na política seria uma característica antropológica, que explicaria nossa cultura imoral e degenerada. Bonfim trata o parasitismo social brasileiro a partir de uma homologia com um organismo biológico doente (BONFIM, 2002). Para Bonfim, o parasitismo social brasileiro e a degeneração moral são explicados pela hereditariedade do mundo ibérico, que sempre esteve associado, em sua história, à exploração do além-mar e de civilizações não-européias, e seu efeito seria o fato de a corrupção estar incrustada na sociedade, definindo um mundo cotidiano de vícios. Para o autor:

Nos grandes, a corrupção faustosa da vida da corte, onde os reis são os primeiros a dar o exemplo do vício, da brutalidade, do adultério: Afonso VI, João V, Filipe V, Carlos IV. Nos pequenos, a corrupção hipócrita, a família

\footnotetext{
${ }^{3}$ Interessante notar, como mostra José Murilo de Carvalho, que nos diferentes momentos de rupturas de regimes, no Brasil, sempre esteve presente o tema da corrupção no interior do debate político e no discurso das forças políticas. Vale lembrar, como mostra o autor, o modo como os revolucionários de 1930 acusavam a Primeira República e seus representantes de carcomidos, o papel do udenismo na denúncia do mar de lama do Catete, o modo como o golpe de 1964 foi dado contra a subversão e contra a corrupção, as denúncias contra a corrupção do regime militar, já no início do período da Nova República. A esse respeito, conferir Carvalho (2008).
} 
do pobre vendida pela miséria aos vícios dos nobres e dos poderosos (BONFIM, 2002, p. 694).

Assim, a corrupção não poupa nem o mundo popular nem os estamentos superiores da sociedade, definindo uma concepção centrada em uma formação distorcida pelos eventos do passado, sendo o brasileiro um desconhecedor das artes, da ciência e dos interesses, que delimitam a sociabilidade do capitalismo e suas instituições. Como não fomos protagonistas da modernidade, criou-se no Brasil um senso permanente de irresponsabilidade e indolência, que definem os traços de uma cultura dos sentimentos, de uma cordialidade intrínseca, incapaz de incorporar o mundo impessoal e de regras formais.

Uma antropologia do Brasil, nessas condições, apenas pode definir a busca desenfreada por vantagens, a malandragem e o jeitinho como condicionantes do caráter do brasileiro. De acordo com Da Matta (1980), o jeitinho e a malandragem respeitam a um processo moral definido no plano de uma cultura da personalidade. O dilema brasileiro, segundo Da Matta, seria explicado por dicotomias entre o certo e o errado, entre o grande e o pequeno, entre a elite e a massa. Essas dicotomias explicariam a situação em que o "você sabe com quem está falando?" se torna uma situação típica da sociedade brasileira. Nesse quadro antropológico, a corrupção seria resultado do jeitinho e da malandragem, que representam estratégias de sobrevivência em meio a uma moralidade social marcada pela distinção.

O problema desse tipo de leitura da realidade brasileira é que o uso de dicotomias especifica muito mais um traço de caráter do que opera nos dois extremos. A corrupção e o jeitinho, dessa forma, são uma estratégia para minimizar os efeitos da distinção entre indivíduo e pessoa. A corrupção, portanto, assumiria uma forma cotidiana, em que esse tipo de interpretação não consegue superar o fato de que o brasileiro teria um caráter de malandro, que sempre usa do artifício da corrupção para obter algum tipo de vantagem. Como observa Souza (2001), interpretações realizadas a partir de dicotomias, como faz Da Matta, tendem a simplificar excessivamente a realidade, sem perceber que a sociedade se constitui de processos mais amplos que configuram a realidade social.

$O$ fato é que diferentes projetos de interpretação do Brasil tomam a corrupção como algo inerente à cultura da personalidade e a diferença entre indivíduo e pessoa e a afirmação de uma cultura da personalidade no Brasil ocorre pela incorporação da sociologia weberiana para interpretar. Do ponto de vista interpretativo, essa cultura delimita um caráter sempre voltado para os vícios e as imoralidades cometidas pelo brasileiro, sem se atentar, contudo, para os processos mais amplos de configuração de uma sociologia política da corrupção no Brasil. 0 caráter do brasileiro, como muitos intérpretes procuram delimitar, termina por estabelecer uma armadilha analítica e conceitual, incapaz de perceber que 
dicotomias mais obscurecem nossas imoralidades do que propriamente as esclarecem. Ao se centrarem no caráter do brasileiro, seja o da cordialidade, o da malandragem ou o da busca estratégica por privilégios, não compreendem a corrupção por seu real alcance no plano da sociedade.

Dessa forma, não há, em uma real sociologia política do Brasil, espaço para análises dicotômicas. No caso da corrupção no Brasil, seu lugar é o da existência de uma antinomia entre o mundo moral e o mundo da prática, porquanto ambos sejam regidos por princípios diferentes que definem uma tensão entre os valores e o mundo real da sociedade brasileira. A análise da corrupção no Brasil, portanto, demanda a construção de mecanismos analíticos capazes de compreender e incorporar essa natureza antinômica da corrupção na política brasileira, capaz de explicar porque o brasileiro tolera a corrupção. A corrupção não está relacionada ao caráter do brasileiro, mas a uma construção social que permite que ela seja tolerada como prática.

\section{A construção do conceito de corrupção}

Afirmamos anteriormente que a temática da corrupção é recente, e que não há uma teoria da corrupção no Brasil, no plano dos pensamentos social e político brasileiros. No caso da literatura especializada, pode-se dizer que o tratamento sistemático sobre a corrupção remonta aos anos 1950, com a emergência de uma perspectiva funcionalista para os estudos das ciências sociais. Os estudos mais sistemáticos sobre o tema da corrupção surgem nos Estados Unidos, tendo em vista o problema da modernização e abordagens comparativas tomando o tema do desenvolvimento (FILGUEIRAS, 2006).

Ao relacionar o problema do desenvolvimento político e econômico ao tema da corrupção, a abordagem funcionalista procura compreender o modo como ela pode contribuir ou emperrar o desenvolvimento de sociedades tradicionais e subdesenvolvidas. Como pano de fundo, há uma preocupação com os processos de modernização, de acordo com um caráter sistêmico que a corrupção assume em sociedades tradicionais. Como já observava Merton (1970), a corrupção é uma função manifesta e latente de sociedades tradicionais, onde a corrupção é a própria norma, em comparação com a modernidade. Como função manifesta, a corrupção tem por consequência fomentar ou impedir a modernização, representando, em muitos casos, eventuais benefícios para a constituição de uma ordem moderna, balizada, principalmente, nas iniciativas do espírito capitalista. Para a sociologia da modernização, há uma relação necessária entre corrupção e modernização, uma vez que cenários de larga corrupção definem uma baixa institucionalização política e, por sua vez, uma ordem fraca para a mediação e a adjudicação de conflitos (HUNTINGTON, 1975). 
Pela abordagem funcionalista, a corrupção seria típica de sociedades subdesenvolvidas, representando um tipo de prática aceita diante da baixa institucionalização política. Os momentos de mudança social favorecem a corrupção pelo hiato existente entre modernização e institucionalização, tornando-a típica de sociedades em processo de mudança social. Em cenários de baixa institucionalização política, como nota Huntington, a corrupção tende a ser um tipo de ação mais acentuada, porquanto a modernização implique novos atores na cena política, ensejando clivagens sociais e um comportamento pouco conducente à norma.

Pela abordagem funcionalista, que se tornou dominante na década de 1960, a corrupção poderia cumprir uma função no desenvolvimento. Se mantida sob controle, a corrupção pode ser uma forma alternativa, encontrada pelos agentes políticos, de articular seus interesses junto à esfera pública. Por exemplo, a construção de máquinas políticas visa a influenciar o conteúdo das decisões tomadas na arena legislativa, por meio da persuasão das elites partidárias. A constituição dessas máquinas políticas, nas quais a corrupção é o elemento chave, colabora para o arrefecimento da disputa entre clivagens sociais que surgem com a modernização, servindo, dessa forma, para o desenvolvimento político, econômico e social (SCOTT, 1969). A corrupção é explicada, portanto, como desfuncionalidade inerente de uma estrutura social de tipo tradicional, que, no contexto da modernidade, gera instabilidade no plano político e econômico. A corrupção, dessa forma, pode cumprir uma função de desenvolvimento, uma vez que ela força a modernização. Porém, sua função de desenvolvimento é cumprida desde que ela esteja sob o controle das instituições políticas, de tipo moderno. Do ponto de vista dos benefícios, a corrupção pode agilizar a burocracia, ao tornar mais rápida a emissão de documentos e autorizações formais por parte do Estado. A corrupção azeita o desenvolvimento ao estabelecer um laço informal entre burocratas e investidores privados que favorece o desenvolvimento econômico (LEFF, 1964).

Ao absorver o problema da modernização como núcleo central para explicar a corrupção, a vertente funcionalista busca compreender os custos e os benefícios da corrupção para o desenvolvimento, de acordo com uma premissa de que seu entendimento considere os aspectos funcionais e disfuncionais dos sistemas políticos. A partir dos anos 1970 , a literatura sobre o tema da corrupção deu uma guinada metodológica, direcionando-se para o tema da cultura e o tema do desenvolvimento passou a ser considerado na dimensão da cultura política, partindo da premissa de que a cultura é proeminente em relação ao político e ao econômico, ao definir os valores dentro da estrutura social. Apesar de essa vertente ter rompido com a questão dos benefícios da corrupção, ao incorporar o problema dos valores, ela não rompeu com a estrutura metodológica do funcionalismo. 
Os trabalhos ligados à conotação da cultura política ligam a corrupção às interações construídas pelos atores sociais, refletindo experiências e valores que permitem ao indivíduo aceitar ou rejeitar entrar em um esquema de corrupção. Ao lado do sistema institucional e legal, o sistema de valores é fundamental para motivar ou coibir as práticas de corrupção no interior de uma sociedade. A modernização implica a mudança dos padrões de valores e de ação por parte dos atores sociais. A corrupção, nessa lógica, representa, antes de tudo, a permanência de elementos tradicionais que utilizam, especialmente, o nepotismo, a patronagem, o clientelismo e a penetração junto à autoridade política para obter vantagens e privilégios. Os trabalhos ligados à vertente da cultura política receberam a influência do trabalho de Edward Banfield sobre culturas locais (BANFIELD, 1958). Nessa vertente, o tratamento da corrupção parte de uma concepção metodológica comparativa, decorrente de culturas locais tradicionais contrapostas a uma cultura universal moderna. Dessa forma, a corrupção dependeria de uma mudança de valores básicos da sociedade que demandariam processos mais lentos de mudança institucional (LIPSET e LENZ, 2002).

Dos anos 1980 para cá, ocorreu uma virada metodológica das pesquisas sobre a corrupção, ao incorporar uma abordagem econômica para um problema político, centrada, principalmente, na análise dos custos da corrupção para a economia de mercado em ascensão. Isso se deve ao fato de, a partir da década de 1980, o tema da corrupção florescer junto com os processos de liberalização econômica e política, especialmente nos países periféricos, como os da América Latina e da Ásia, e nos países do Leste-Europeu e na Rússia (JOHNSTON, 2005). Ademais, a literatura de viés econômico sobre o tema da corrupção percebeu que os custos superam os benefícios apontados pela teoria funcionalista. A literatura especializada sobre o tema da corrupção, dos anos 1980 para cá, tem sido dominada pela economia, de maneira a compreendê-la como o resultado de configurações institucionais e o modo como elas permitem que agentes egoístas autointeressados maximizem seus ganhos burlando as regras do sistema político (ROSE-ACKERMAN, 1999). O problema da corrupção é explicado de acordo com conceitos derivados de pressupostos econômicos como o rent-seeking e a ação estratégica de atores políticos no contexto de instituições que procuram equilibrar esses interesses com noções amplas de democracia (FILGUEIRAS, 2008b).

A corrupção é explicada por uma teoria da ação informada pelo cálculo que agentes racionais fazem dos custos e dos benefícios de burlar uma regra institucional do sistema político, tendo em vista uma natural busca por vantagens. Basicamente, a configuração institucional define sistemas de incentivos que permitem aos atores acumularem utilidade. Uma postura rent-seeking, que é esperada quando as instituições permitem que um agente burle as regras do sistema, ocorre quando ele maximiza sua renda privada em detrimento dos 
recursos públicos (KRUEGER, 1974; TULLOCK, 1967). Dessa forma, situações de monopólio de poder e de recursos favorecem situações em que os agentes preferem cometer a corrupção do que seguir as regras do sistema.

As proposições de reformas institucionais, derivadas dessa vertente econômica de análise da corrupção, tendem a ver o Estado - que detém o monopólio do uso da força - como uma instituição naturalmente corrompida, o lugar privilegiado dos vícios e da malversação de recursos, e devem caminhar no sentido de minimizar seu papel na sociedade e reduzir os incentivos para a prática da corrupção, por meio da redução do poder da burocracia (ANECHIARICO e JACOBS, 1996). Pelo postulado econômico, a democracia e os sistemas de probidade, devem seguir as regras do mercado, porquanto seja esse o mundo da impessoalidade e uma estrutura competitiva que minimiza os sistemas de incentivo à corrupção. A par disso, a literatura contemporânea tem se dedicado a pensar os sistemas de integridade pública na dimensão da sociedade civil, da mídia e de outros atores importantes no controle da corrupção. Afirma-se, em confrontação com os aspectos econômicos da corrupção, um aspecto público e mais orientado ao político. Reforça-se a ideia de accountability pela via da democracia, em que o problema do controle da corrupção demanda um processo de democratização do Estado que está além da questão administrativa e burocrática (WARREN, 2004).

O problema dessa abordagem econômica é que ela tende a naturalizar a corrupção na órbita dos interesses materiais, sem perceber que ela está relacionada a processos sociais e, por conseguinte, simbólicos. Assim, a corrupção, para além da questão propriamente monetária e contábil, está relacionada a processos sociais que levam em consideração valores e normas que, além do institucional e do formal, consideram aspectos informais e culturais. A análise da corrupção deve atender a esses aspectos sociológicos implicados no reconhecimento de normas formais e informais, porquanto a passagem do privado ao público ocorre em meio a configurações de valores e normas. Ou seja, é fundamental pensar o aspecto normativo envolvido no conceito de corrupção, porque ele tem uma natureza fugidia, já que depende de concepções normativas a respeito das próprias instituições sociais, em que pesem, dessa forma, os valores que definem a própria noção do que vem a ser o interesse público.

É fundamental pensar a corrupção em uma dimensão sistêmica que alie a moralidade política - pressuposta e que estabelece os significados da corrupção . com a prática social propriamente dita, na dimensão do cotidiano. Resgatar uma dimensão de moralidade para pensar o tema da corrupção significa buscar uma visão abrangente que dê conta dos significados que ela pode assumir na esfera pública. É a partir dessas significações que podemos observar as formas que ela pode assumir na sociedade, de acordo com aspectos políticos, sociais, culturais e econômicos. Na próxima seção, apresento um modelo de análise da corrupção. 


\section{Um modelo analítico para o estudo da corrupção no Brasil}

A corrupção, dessa forma, pode ser compreendida levando-se em consideração aspectos morais que estão pressupostos na prática social ordinária. É fundamental considerar os aspectos normativos envolvidos no tema da corrupção e o modo como a construção de sua significação social depende de valores que circulam no plano da sociedade. A legitimidade da ação política apenas é construída com a pressuposição desses valores fundamentais que configuram o que é e o que não é corrupção; ou seja, valores que configuram uma antinomia entre interesse público e corrupção, tendo em vista concepções de mundo e valores diferentes na moralidade política ${ }^{4}$. Por esse postulado, a corrupção deve ser analisada em uma dimensão sistêmica que considere, de um lado, a existência de valores e normas que tenham uma conformação moral e, de outro lado, a prática social realizada no âmbito do cotidiano de sociedades.

Argumento que esses valores nascem de um processo deliberativo e têm uma natureza consensual no interior da ordem política, porquanto representam categorias com as quais todos possam concordar e que consideram importantes para a configuração de um bom governo (FILGUEIRAS, 2008a). Ou seja, a compreensão da corrupção nasce de concepções consensuais definidas como valores normativos fundamentais, que têm uma natureza linguística originada comunicativamente de acordo com concepções de bom governo e só pode ocorrer no âmbito de uma sociologia das relações de poder, de acordo com as significações que ela pode assumir na sociedade. Essas significações são derivadas de um processo hermenêutico realizado na esfera pública, de acordo com consensos normativos estabelecidos deliberativamente, os quais definem conteúdos substantivos de valores - no plano da moralidade política - e definem sua contraparte normativa da corrupção.

A corrupção, no plano da moralidade política, deve ser compreendida a partir de valores pressupostos, conforme concepções normativas de interesse público que configuram o que é e o que não é corrupção, tendo em vista normas que têm um caráter formal ou informal. Por esta assertiva, a corrupção espelha, sobretudo, uma natureza moral que depende dos juízos que atores relevantes fazem a respeito da ordem política. Assim, a corrupção é, consequentemente, um juízo moral

4 Importante frisar que me refiro à moralidade como valores sociais básicos, que definem a responsabilidade do indivíduo frente à sociedade. Não trato, neste artigo, de termos éticos, porque não pressuponho a existência de valores particulares. Dessa forma, a confrontação entre ética e moral perpassa o argumento, à medida que o conceito de corrupção tem uma conotação normativa, tendo em vista a questão da correção de normas morais. Nesse sentido, termos como decoro, honestidade, confiança e respeito têm um caráter normativo de posições corretas do indivíduo frente à sociedade, que nem sempre serão éticas, do ponto de vista de definições do bem. Tratar da moralidade, portanto, não significa uma abordagem moralista, uma vez que não questiono se a corrupção é boa ou ruim, se tem custos ou benefícios. A esse respeito, conferir Habermas (2004). 
(FILGUEIRAS, 2008a), com base no qual consideramos determinada ação política correta ou incorreta, de acordo com valores pressupostos que definem um conteúdo normativo da moralidade. Dessa forma, quando dizemos, no plano do discurso político, que determinado agente A é desonesto, usou indevidamente os recursos públicos, cometeu uma improbidade administrativa, usou de clientelismo para se eleger ou simplesmente utiliza seu poder para obter alguma vantagem, julgamos que ele cometeu um ato de corrupção.

O modelo analítico parte de uma concepção habermasiana da questão da moralidade, em que a construção da ação política legítima depende da justificação e aplicação racional de valores e normas (HABERMAS, 2004). Os consensos normativos constituem-se como expectativas normativas e são fundamentados na práxis pública de justificação racional de valores por parte de uma comunidade de comunicação, visando estabelecer a verdade de enunciados normativos em função de razões justificadoras, as quais asseguram um processo de aprendizado moral. Isso é, as convicções normativas partilhadas intersubjetivamente têm uma função cognitiva que levam as partes conflitantes a um constante experimentar de normas colocadas à deliberação. O saber moral é sempre empregado na construção dos consensos normativos, tendo em vista o fato de a justificação racional de normas ocorrer em paralelo à sua constante crítica. A moralidade, desse modo, tem uma função epistêmica e uma natureza de correção, que opera com justificações racionais dadas ao entendimento. A fundamentação de normas morais, de acordo com Habermas, ocorre por uma atitude autocrítica nos contextos de aplicação, a par de uma troca empática das perspectivas de interpretação oferecidas por contextos de justificação. Os juízos envolvem uma moralidade configurada em torno de uma justificação racional de valores dados à aplicação por meio de normas que assumem uma natureza jurídica no plano formal, e cultural no plano informal ${ }^{5}$.

Portanto, quando dizemos que um agente $A$ cometeu um ato de corrupção, tomamos como conteúdo do juízo moral expectativas normativas, que têm uma natureza consensual na esfera pública. Espera-se que esse mesmo político A seja honesto, aja com decoro e respeito aos deveres cívicos, atenda às necessidades da sociedade, seja capaz de legislar e executar normas que visem à segurança da comunidade, aloque recursos da maneira o mais eficiente e trate a coisa pública de modo exemplar. Ao contrário disso, julgamos a ação desse mesmo político como um ato de corrupção. Por essa assertiva, o conceito de corrupção não se resume aos interesses dos agentes, nem mesmo às normas jurídicas do ordenamento político, assumindo um caráter plástico que apenas pode ser definido no contexto linguístico, em que esses juízos são realizados (FILGUEIRAS, 2008a).

\footnotetext{
${ }^{5}$ A respeito do conteúdo da moralidade política e dos consensos normativos, conferir Filgueiras (2008a).
} 
A moralidade política, nesse sentido, congrega preferências fortes por valores e normas definidos consensualmente, permitindo ao sujeito julgar a ação política com base em princípios legitimadores, que têm uma forma geral e pressuposta, de acordo com expectativas de ação corretas por parte dos agentes e das instituições. De um modo geral, seguindo a trilha de Charles Taylor (1992), esses juízos estão referidos às preferências fortes, porquanto sejam formas de julgamento entrelaçadas às identidades existentes no plano da comunidade política, assumindo um caráter formal por meio do Direito e um caráter informal definido no plano da cultura. Os juízos morais, dessa maneira, espelham um quadro normativo que organiza a ação política.

Os juízos morais podem ser diferenciados em juízos de valor e juízos de necessidade (FILGUEIRAS, 2008a), de acordo com a diferenciação entre excelência e cotidiano, explorada por Taylor (1992). Excelência e cotidiano, segundo Taylor, especificam uma antinomia moral, própria à modernidade, entre os objetivos da vida boa, seguindo a ética aristotélica, e os objetivos defensivos e econômicos, como marcados pela filosofia política moderna, originada de Locke. A boa vida, como aponta a ética aristotélica, apreendida por Taylor, é uma finalidade da associação política, tendo em vista a identificação entre os indivíduos em torno de valores comuns, pertencentes a uma ordem de distinção. De outro lado, a vida cotidiana é aquela que assegura a reprodução da ordem através da solidariedade em torno de necessidades vitais. A vida cotidiana é uma forma de associação exclusivamente privada, porque o self pontual, substancialmente produtor e reprodutor, associa-se exclusivamente pelos objetivos econômicos e defensivos.

Os juízos morais de valor dependem de relações empáticas que identificam os atores, porque se mobiliza o conceito de corrupção para descrever a não excelência da ação do corpo político, em função de uma configuração de valores que orienta o agir em contextos sociais complexos. Elementos como decoro, honestidade, cumprimento dos deveres e virtudes demandam do comportamento dos atores normas entronizadas, que são aplicadas pela ação virtuosa e pelo respeito aos costumes de determinada comunidade política singular.

De outro lado, os juízos morais de necessidade estão ligados à vida cotidiana, fundamentam a solidariedade como mecanismo primordial da moralidade. Não se espera do corpo político a excelência do agir, mas apenas uma neutralidade em relação a valores, que permita a cada indivíduo satisfazer suas necessidades. Em sociedades complexas, alicerçadas na vida cotidiana, cabe ao Estado, em face da divisão do trabalho social, a realização moral do indivíduo. A justificação racional da segurança e da liberdade demanda apenas a afirmação de normas que assegurem, respectivamente, a aplicação mediante a obediência e os direitos, que atuam no plano externo do indivíduo, em vista de um consentimento. 
O fato é que a distinção entre a vida por excelência e a vida cotidiana, e, por sua vez, a distinção entre os juízos de valor e os juízos de necessidade permitem especificar uma antinomia da moralidade política, que tenciona o conceito de corrupção no plano da prática social. A corrupção tem uma natureza moral e prática, que nem sempre são conexas, o que não quer dizer que ela deva ser tolerada em função de sua natureza complexa.

Até agora, especificamos o aspecto moral da corrupção, sem nos atermos ao aspecto propriamente prático. Tratar da moralidade política significa especular sobre os significados linguísticos da corrupção (FILGUEIRAS, 2008a). Contudo, esses significados necessitam de uma teoria da prática que os assente em uma realidade empírica. Os juízos morais de valor e de necessidade entrelaçam-se na prática social, representando situações de crítica à ordem política e suas instituições. Contudo, como toda forma de julgamento, os juízos morais da corrupção representam situações contraditórias e posições contingentes, espelhando um processo permanente de confrontação da livre opinião formada na esfera pública e nas instituições (FILGUEIRAS, 2008a).

Seguindo a teoria das práticas de Bourdieu, procura-se superar o fosso que separa a ação dos agentes e a estrutura social, bem como superar o problema da consciência e da racionalidade. A prática social, segundo Bourdieu, correlaciona consciência e inconsciência, racionalidade e irracionalidade, no sentido de rebaixar o poder da razão e do sujeito na produção do conhecimento (BOURDIEU, 2005). Do ponto de vista de uma teoria das práticas, o estudo sociológico concentra-se nas estruturas estruturantes, fazendo com que o estudo da ação ocorra pelas disposições dos atores conforme os espaços sociais e seu capital cultural. Ou seja, de acordo com o autor, o estudo da razão prática demanda o estudo do conhecimento social pressuposto e do modo como ele é representado na sociedade.

A ciência social, como atesta Bourdieu (2005), deve recusar as alternativas da consciência e da inconsciência, da racionalidade e da irracionalidade, visto que dicotomias conceituais encobrem os processos pelos quais os fatos sociais ocorrem. O conceito de habitus, nesse sentido, procura superar as dicotomias em teoria social, atrelando às práticas cotidianas o conhecimento moral da sociedade. No que diz respeito à política, a ação não é nem intencional nem espontânea, e sim depende do conjunto de interações e do capital cultural acumulado, que vincula os fenômenos políticos às manifestações públicas e ao ato público no contexto das instituições. A sociologia da política não deve estar assentada na dicotomia ação e estrutura, mas no conjunto das práticas sociais que não são nem racionais nem 
irracionais, porém, localizadas no habitus criado no conjunto do mundo cotidiano da sociedade ${ }^{6}$.

Analisar a corrupção em seu sentido prático, seguindo a trilha de Bourdieu, não significa dissociá-la dos valores fundamentais da moralidade política. Significa, de acordo com o autor, atestar as antinomias do mundo social e suas contradições, no sentido de perceber uma estrutura onde essa prática ocorre. De acordo com Bourdieu, no caso da política, é fundamental pensar os elementos práticos informados pelo teste moral de universalização. Como aponta o autor:

Colocar a questão da moral na política ou da moralização da política em termos sociologicamente realistas significa interrogar-se, de modo muito prático, a respeito das condições que deveriam ser preenchidas para que as práticas políticas fossem submetidas, permanentemente, a um teste de universalizabilidade; para que o próprio funcionamento do campo político imponha aos agentes aí engajados em tempo integral limitações e controles tais que eles sejam obrigados a seguir estratégias reais de universalização. Vemos que se trataria de instituir universos sociais no quais, como na república ideal de Maquiavel, os agentes teriam interesse na virtude, no desinteresse, no devotamento ao serviço público e ao bem comum.

A moral política não cai do céu; ela não está inscrita na natureza humana. Apenas uma Realpolitik da Razão e da Moral pode contribuir para implementar a instauração de um universo no qual todos os agentes e seus atos estariam submetidos - especialmente pela crítica - a uma espécie de teste de universalizabilidade permanente, instituído praticamente na própria lógica do campo. (BOURDIEU, 1996, p. 221).

A moralidade política especifica os valores que fundamentam o julgamento moral da corrupção que significam, dessa forma, pressupostos que informam o conteúdo do julgamento moral, como demandado por Bourdieu. A tolerância à corrupção, portanto, ocorre exatamente no espaço entre os juízos de valor e os

\footnotetext{
6 O conceito de habitus é um tipo de operação teórica preocupada com as disposições, os modos de perceber, de pensar e de sentir que levam os atores a agirem de uma maneira, em uma circunstância dada. Essas disposições para a ação, como circunscreve Bourdieu em relação ao conceito de habitus, não são determinadas nem mecânicas. São produtos de uma aprendizagem social, flexível e plástica, porquanto constituem o modo de valorizar e julgar o mundo. O habitus conforma a ação a certos princípios construídos pelos valores em estado prático e, portanto, não conscientes. Como afirma o autor, o habitus é estruturado e estruturante, visto que são disposições interiorizadas pelos indivíduos, no plano da estrutura, e geradoras de práticas e representações coletivas, no plano da estruturação. 0 habitus não depende de uma consciência ou de um cálculo racional dos fins, porque é o princípio de um conhecimento social não consciente, adquirido cognitivamente conforme mecanismos de percepção e valoração do mundo cotidiano.
} 
juízos de necessidade, ou seja, entre o limite dos valores e o limite das necessidades, representando uma antinomia própria das sociedades contemporâneas. Por essa assertiva, nota-se que moralidade e prática social têm um aspecto contraditório, uma vez que podemos concordar com valores morais universais, como por exemplo, o valor da honestidade, ao mesmo tempo em que podemos agir de forma desonesta. Isso explica o fato de criarmos a expectativa de que os políticos e cidadãos sejam honestos, mas o sujeito, ao mesmo tempo, querer entrar em um esquema de corrupção, tendo em vista interesses bem determinados, na esfera econômica e social. A antinomia entre juízos de valor e juízos de necessidade permite compreender a antinomia existente entre moralidade e prática social, explicando a tolerância à corrupção nas sociedades contemporâneas.

A antinomia entre normas morais e prática social cria um contexto de tolerância à corrupção que explica o fato de atores, consensualmente, concordarem com a importância de valores fundamentais como respeito, honestidade, decoro e virtudes políticas, mas, ao mesmo tempo, concordarem que, na política, um pouco de desonestidade pode cumprir uma função importante. Em um sentido bastante maquiaveliano, é importante distinguir a política do mundo real e os valores normativos que são passíveis de acordo racional, o que explica esse contexto de tolerância. É dessa forma que a corrupção é normal à política, apesar de todos os esforços para impedi-la ${ }^{7}$. Os juízos morais de valor - pautados pela vida pela excelência - e os juízos de necessidade - pautados pela vida cotidiana - explicam a antinomia existente entre normas morais e prática social da corrupção, de acordo com a definição de limites teóricos que a circunscrevem. Ou seja, de acordo esses limites, é possível definir uma taxonomia da corrupção conforme seu alcance na prática social. A corrupção pode ser controlada, tolerada ou endêmica, de acordo com seu alcance prático na sociedade. A figura a seguir procura representar, graficamente, essa taxonomia da corrupção:

7 O caráter de normalidade da corrupção não significa que ela possa trazer benefícios para o desenvolvimento ou algo parecido. Seguindo a linha de Durkheim (2003), a corrupção é normal desde que não represente um processo de decadência institucional (patologia) da sociedade. Por ser normal, ela precisa ser combatida e punida, porquanto se sair de controle, pode contribuir para a decadência de instituições. 


\section{Figura 1 \\ Os Patamares da Corrupção na Política}

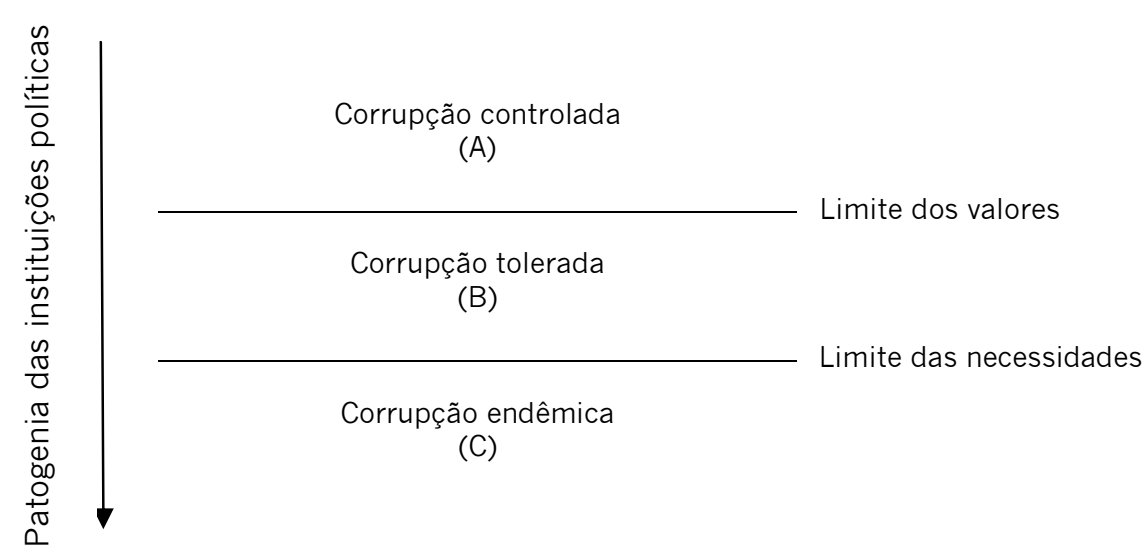

No caso da corrupção controlada (A), não há antinomia entre normas morais e prática social, representando uma situação ideal em que valores e necessidades convergem em uma razão prática que mantém a corrupção sob controle. Esse tipo de corrupção pressupõe uma sociedade estóica e dirigida pelos deveres, funcionando como uma espécie de modelo normativo perfeito, mas que não encontra efetividade no mundo real. No caso da corrupção tolerada (B), está presente a antinomia entre valores e necessidades, em que os atores sociais são capazes de concordar com os valores fundamentais da política, mas, no plano prático, não transformam esses significados morais em uma prática efetiva. A tolerância à corrupção está relacionada a contextos sociais marcados pelo mundo dos interesses cotidianos, em que a atividade política é realizada na dimensão da representação. Finalmente, no caso da corrupção endêmica (C), a antinomia entre valores e necessidades desaparece pela ausência de significados morais para a vida social e uma prática predatória, marcada por baixa solidariedade. Esse cenário ocorre em contextos pouco comuns, mas empiricamente encontrados, representando situações de rupturas políticas e decadência institucional.

Taxonomias semelhantes a essa, que especulam sobre a tolerância da corrupção no contexto de sociedades democráticas, já foram produzidas, como no trabalho de Heidenheimer (2001). O autor buscou os critérios de tolerância à corrupção pela análise de variáveis atitudinais que revelem o modo como os cidadãos percebem e combatem a corrupção, ao mesmo tempo em que ela pode ser encarada como uma prática corriqueira no cotidiano da vida social. Nesse sentido, de acordo com Heidenheimer (2001, p. 152), a corrupção pode ser negra, cinza ou branca: é negra quando as elites políticas e a opinião pública formam um consenso de que a corrupção deve ser punida por razão de princípio; é cinza 
quando as elites e a opinião pública não formam esse consenso a respeito da punição da corrupção, fazendo com que alguns concordem com sua punição por princípio e outros não e, finalmente, é branca quando a corrupção ganha um aspecto tolerável, em que não existe apoio público à punição.

A taxonomia de Heidenheimer leva em consideração o fato de que a tolerância à corrupção espelha o apoio público à imputação de punições a casos de corrupção. A tolerância à corrupção é explicada por Heidenheimer (2001) pelo caráter atitudinal de apoio das elites políticas e da opinião pública de massas a uma cultura da punição e da criação de sistemas de vigilância à corrupção. Ou seja, o autor procura equilibrar variáveis de percepção da corrupção com a prática de punição no interior de sociedades. Especulo, ao contrário, que a tolerância à corrupção, como expusemos acima, nasce de antinomias existentes na cultura política de fundo, tendo em vista as contradições espelhadas na avaliação da opinião pública de casos de corrupção. O objetivo da taxonomia exposta, considerando a corrupção controlada, a corrupção tolerada e a corrupção endêmica, não é contrastar o apoio público à punição da corrupção, mas contrastar o modo como os indivíduos avaliam a corrupção em confrontação com os aspectos morais - de acordo com valores e normas - e prática social - no âmbito do cotidiano. Pensar a corrupção negra significa especular sobre um sistema de vigilância à corrupção muito próximo de formas autocráticas de poder. Isso é, nas democracias é normal alguma tolerância à corrupção, desde que ela não se torne um tipo de endemia social.

Do ponto de vista teórico, esse modelo analítico permite investigar as razões pelas quais indivíduos toleram a corrupção, sendo esse o cenário típico das sociedades contemporâneas. Na modernidade, a corrupção é tolerada como uma prática normal, o que não quer dizer que ela seja correta. A corrupção controlada é um tipo ideal em que moralidade política e a prática social coincidem, pressupondo uma sociedade homogênea - e porque não autocrática - onde não há divergência a respeito dos valores políticos básicos e das práticas sociais corretas e incorretas. Seria, grosso modo, uma cidade platônica, governada por um demiurgo. A corrupção endêmica parte da assunção de que é possível a corrupção representar os momentos de decadência institucional porquanto não há consenso a respeito dos valores políticos básicos e muito menos a respeito de quais práticas são permitidas no âmbito da sociedade. Ou seja, representa uma situação em que a corrupção esteja associada a uma possível falta de sociabilidade. A próxima seção cuida de analisar, empiricamente, a corrupção a partir desse modelo de análise, tomando o caso do Brasil, de acordo com os resultados do survey Os brasileiros e a corrupção ${ }^{8}$.

\footnotetext{
${ }^{8}$ Survey realizado pelo Centro de Referência do Interesse Público (CRIP) da Universidade Federal de Minas Gerais (UFMG) aplicado à amostra nacional entre 10 e 16 de maio de 2008, pelo instituto Vox Populi. A amostra foi estratificada pelas regiões do território brasileiro e aplicada a um universo de 2421
} 


\section{A tolerância à corrupção no Brasil}

Boa parte das pesquisas relizadas a respeito do tema da corrupção tem considerado como elemento primordial para sua compreensão a percepção que cidadãos comuns têm a respeito dela. Como destaca Abramo (2005), o problema de abordar a corrupção empiricamente é o fato de não haver uma forma de medição direta desse fenômeno, o que pode significar o fato de ser possível que essas pesquisas apresentem vieses e controvérsias interpretativas, que pouco esclarecem o seu real alcance na sociedade.

Abramo crítica o Índice de Percepção da Corrupção da Transparência Internacional ( $\mathrm{TI})$, que faz um ranking da corrupção para diferentes países, tendo como primeira objeção o fato de permitir inclinações ideológicas. A segunda objeção está no fato de haver uma imprecisão estatística dada por uma escala de 0 a $10 \mathrm{com}$ intervalos de confiança que podem chegar a 2. Como o autor mostra, casos como o do Suriname, em que o índice equivale a 3,6, um intervalo de confiança de 2,0 pode colocá-lo numa posição de corrupção sistêmica ou, ao mesmo tempo, de razoável controle. A terceira objeção à ideia de percepção está no fato de os dados de cada país serem escalonados em um ranking. A rigor, se um país melhora $n$ posições no ranking, isso significa que outro descendeu $n$ posições, podendo haver a hipótese de a corrupção nesse segundo país não ter se alterado, apesar de ele cair no ranking. A quarta objeção é que a montagem de um ranking não oferece uma compreensão mais ampla a respeito dos sistemas de integridade dos diferentes países. Isso não permite uma comparação entre eles, nem mesmo de boas experiências de controle da corrupção. Por fim, o autor formula uma quinta objeção, subsidiária, que estaria na possibilidade de uso instrumental do ranking (ABRAMO, 2005, p. 34-35).

As críticas apresentadas apontam para a vulnerabilidade do conceito de percepção, uma vez que coletar uma medida de corrupção pela percepção significa compreendê-la por algo que é volúvel e suscetível à exposição por parte da mídia. Governos normalmente justificam um suposto aumento da corrupção pelo modo como ela é desvelada pela mídia e sua influência na opinião pública. Acertadamente, Abramo aponta a cautela que devemos adotar com relação ao conceito de percepção, uma vez que ele não significa uma medida direta do fenômeno empírico, mas uma medida indireta que não permite uma conclusão a respeito da corrupção existente em determinado país. No caso brasileiro, as séries

indivíduos maiores de 16 anos. As cotas utilizadas para a seleção dos entrevistados foram: situação do domicílio, gênero, idade, escolaridade, renda familiar e situação perante o trabalho, calculadas proporcionalmente a cada estrato de acordo com os dados do IBGE, Censo 2000 e PNAD 2006. O survey tem um nível de confiança de $95 \%$ e margem de erro de $+/ \cdot 2,0 \%$. A pesquisa constou da aplicação de questionários estruturados a essa população. 
históricas realizadas pela Transparência Internacional, em parceria com o IBOPE, demandam esse cuidado porque não revelam o tamanho da corrupção no país, mas aspectos que podem ser considerados na compreensão que a sociedade tem da corrupção.

Apesar de ser uma medida indireta, consideramos que a questão da percepção pode revelar traços dos elementos culturais da corrupção. É nessa dimensão que o conceito de percepção da corrupção pode ser útil, ou seja, pode revelar uma cultura política de fundo informada por perspectivas atitudinais delimitadas por variáveis abrangentes e indiretas. Por percepção da corrupção compreendemos uma medida indireta balizada no modo como os indivíduos descrevem o fenômeno. A percepção, nesse sentido, tem dois elementos que precisam ser considerados: (1) o elemento propriamente descritivo em que o indivíduo delineia certo objeto; (2) os parâmetros utilizados para realizar a descrição. Um indivíduo percebe algo quando formula impressões a respeito do objeto com base em parâmetros pressupostos para a sua compreensão. Nesse caso, partimos da premissa de que a percepção da corrupção por parte do cidadão comum significa sua capacidade de descrever e avaliar a corrupção com base em parâmetros morais definidos previamente. Como afirmamos anteriormente, na terceira seção deste artigo, a corrupção expressa um juízo moral, em que o indivíduo avalia a ação praticada por um agente com base em uma moralidade pressuposta, fundamentada em consensos a respeito de valores e normas que organizam concepções de bom governo.

Do ponto de vista da análise empírica da tolerância da corrupção no Brasil, nos pautamos em uma pesquisa de percepção, tomando o cuidado de recortar o modo como ela é percebida no âmbito da cultura política. Os dados expostos não revelam uma medida direta da corrupção, mas uma medida indireta que procura a forma como ela é percebida na dimensão da opinião pública brasileira. A análise empírica da corrupção no Brasil, com base no modelo analítico apresentado, está baseada em um survey realizado pelo Centro de Referência do Interesse Público (CRIP), da Universidade Federal de Minas Gerais (UFMG).

A pesquisa procurou compreender o modo como o brasileiro percebe 0 problema da corrupção na política, de maneira a configurar uma visão geral que permita compreender noções gerais de conceitos políticos e o modo como essa percepção é construída no sentido de tornar a corrupção tolerada. É importante ressaltar que o modo como a corrupção se torna aparente nos meios de comunicação pode alterar a sua percepção, sendo volátil e suscetível à mídia, bem como marcada por muitos aspectos subjetivos. Contudo, neste artigo, analiso aspectos relacionados à tolerância à corrupção na política brasileira, tendo em vista, uma antinomia entre normas morais e prática social. 0 tratamento segue um recorte na dimensão da cultura política,através do qual procuro pelas normas 
morais que funcionam como parâmetro da percepção da corrupção em contraposição ao modo como os indivíduos descrevem algumas práticas sociais. A tolerância à corrupção, baseada na noção que apresento de percepção, deriva do modo como o brasileiro compreende determinadas normas morais em confrontação com concepções práticas. Não esgoto as possibilidades do survey, mas apresento alguns dados relacionados à dimensão da cultura política.

Em primeiro lugar, chamo a atenção para os modos de acordo com os quais o brasileiro compreende o conceito de interesse público. Procuro contrastar noções de interesse público que se ligam exclusivamente a uma noção de Estado com concepções de interesse público ligadas a uma noção de responsabilidade coletiva ou utilitária, sendo, nesse último caso, o interesse público compreendido como aquilo que interessa ao maior número de pessoas. As noções de interesse público expostas influenciam no modo como o brasileiro pensa a corrupção. De acordo com os dados, a corrupção no Brasil está ligada a atos ilícitos praticados por funcionários públicos, não percebendo a possibilidade de a corrupção poder ser praticada na dimensão privada (Tabela 1): 
Tabela 1

Concepções de interesse público

\begin{tabular}{|l|c|c|c|}
\hline \multicolumn{1}{|c|}{ Categorias } & $\mathbf{N}$ & $\mathbf{\%}$ & \% Válido \\
\hline $\begin{array}{l}\text { É qualquer coisa que interessa à maioria } \\
\text { das pessoas }\end{array}$ & 483 & 20,0 & 20,9 \\
\hline $\begin{array}{l}\text { Alguma coisa que é responsabilidade do } \\
\text { Estado resolver }\end{array}$ & 548 & 22,6 & 23,8 \\
\hline $\begin{array}{l}\text { Alguma coisa que é de responsabilidade de } \\
\text { todos nós resolvermos }\end{array}$ & 961 & 39,7 & 41,7 \\
\hline $\begin{array}{l}\text { Todas as frases explicam do mesmo modo } \\
\text { o que é interesse público. }\end{array}$ & 298 & 12,3 & 12,9 \\
\hline $\begin{array}{l}\text { Nenhuma das frases explica o que é } \\
\text { interesse público }\end{array}$ & 16 & 0,7 & 0,7 \\
\hline $\begin{array}{l}\text { Não sabe } \\
\text { Não respondeu }\end{array}$ & 112 & 4,6 & \\
\hline Total & 2421 & 100,0 & \\
\hline
\end{tabular}

Fonte: Centro de Referência do Interesse Público / Vox Populi, 2008

No âmbito do survey, perguntou-se qual tipo de corrupção prejudicaria mais o Estado, se aquela praticada exclusivamente por funcionários públicos, ou aquela que pode ser praticada por qualquer pessoa. Ao analisar a Tabela 2, verifica-se que $45,4 \%$ da amostra pensam que "Um ato que prejudica o Estado praticado por um funcionário público ou político" é a mais corrupta das situações. 29,1\% acreditam que a situação mais corrupta é "Um ato que prejudica o Estado praticado por qualquer pessoa" e $21,9 \%$ creem que "As duas situações são igualmente corruptas". 
Tabela 2

Situações de corrupção

\begin{tabular}{|l|c|c|c|}
\hline \multicolumn{1}{|c|}{ Categorias } & N & \% & \% Válido \\
\hline $\begin{array}{l}\text { Um ato que prejudica o Estado praticado } \\
\text { por funcionários públicos ou políticos }\end{array}$ & 1099 & 45,4 & 46,9 \\
\hline $\begin{array}{l}\text { Um ato que prejudica o Estado praticado } \\
\text { por qualquer pessoa }\end{array}$ & 704 & 29,1 & 30,1 \\
\hline $\begin{array}{l}\text { As duas situações são igualmente } \\
\text { corruptas }\end{array}$ & 530 & 21,9 & 22,6 \\
\hline Nenhuma das situações é corrupta & 8 & 0,3 & 0,3 \\
\hline Não sabe & 77 & 3,2 & \\
\hline Não respondeu & 3 & 0,1 & \\
\hline Total & 2421 & 100 & \\
\hline
\end{tabular}

Fonte: Centro de Referência do Interesse Público / Vox Populi, 2008

Cruzando as duas questões, obtém-se uma associação entre as duas variáveis, em que concepções de interesse público influenciam o modo como os brasileiros percebem situações de corrupção. Nesse caso, o modo como o brasileiro compreende a questão do interesse público, afirmando que ele é de responsabilidade do Estado, implica o fato de ele compreender a corrupção como praticada por funcionários públicos. Como o interesse público representa, na dimensão do imaginário coletivo brasileiro, uma ideia de interesse do Estado, é esperarado que a corrupção seja compreendida na esfera estatal e não na dimensão da sociedade em seu conjunto. Nesse caso, a cultura política vincula, de alguma maneira, o tema da corrupção ao tema do Estado, sem perceber a corrupção que é praticada na dimensão da sociedade. 
Tabela 3

Tabela de contingência da associação entre concepções de interesse público e concepções de corrupção

\begin{tabular}{|c|c|c|c|c|c|c|}
\hline \multirow{2}{*}{\multicolumn{2}{|c|}{$\begin{array}{c}\text { Qual das frases explica melhor } \\
\text { o que é "interesse público" }\end{array}$}} & \multicolumn{5}{|c|}{ Qual das situações é a mais corrupta } \\
\hline & & \multirow{2}{*}{$\begin{array}{l}\text { Um ato que } \\
\text { prejudica o } \\
\text { Estado } \\
\text { praticado por } \\
\text { funcionário } \\
\text { público ou } \\
\text { político } \\
284\end{array}$} & \multirow{2}{*}{\begin{tabular}{|c|}
$\begin{array}{c}\text { Um ato que } \\
\text { prejudica } \\
\text { Estado, } \\
\text { praticado } \\
\text { por qualquer } \\
\text { pessoa }\end{array}$ \\
126 \\
\end{tabular}} & \multirow{2}{*}{$\begin{array}{c}\begin{array}{c}\text { As duas } \\
\text { situações } \\
\text { são }\end{array} \\
\text { igualmente } \\
\text { corruptas }\end{array}$} & \multirow{2}{*}{\begin{tabular}{|c}
$\begin{array}{c}\text { Nenhuma } \\
\text { das duas } \\
\text { situações é } \\
\text { corrupta }\end{array}$ \\
0
\end{tabular}} & \multirow{2}{*}{$\begin{array}{l}\text { Total } \\
\\
477 \\
\end{array}$} \\
\hline \multirow{2}{*}{$\begin{array}{l}\text { É qualquer coisa que } \\
\text { interessa à maioria das } \\
\text { pessoas }\end{array}$} & $\mathrm{N}$ & & & & & \\
\hline & $\%$ & 59,5 & 26,4 & 14,0 & 0,0 & 100,0 \\
\hline \multirow{2}{*}{$\begin{array}{l}\text { Alguma coisa que é } \\
\text { responsabilidade do } \\
\text { Estado resolver }\end{array}$} & $\mathrm{N}$ & 287 & 176 & 77 & 1 & 541 \\
\hline & $\%$ & 53,0 & 32,5 & 14,2 & 0,2 & 100,0 \\
\hline \multirow{2}{*}{$\begin{array}{l}\text { Alguma coisa que é de } \\
\text { responsabilidade de todos } \\
\text { nós resolvermos }\end{array}$} & $\mathrm{N}$ & 445 & 332 & 175 & 2 & 954 \\
\hline & $\%$ & 46,6 & 34,8 & 18,3 & 0,2 & 100,0 \\
\hline \multirow{2}{*}{$\begin{array}{l}\text { Todas as frases explicam } \\
\text { do mesmo modo o que é } \\
\text { interesse público }\end{array}$} & $\mathrm{N}$ & 51 & 54 & 182 & 4 & 291 \\
\hline & $\%$ & 17,5 & 18,6 & 62,5 & 1,4 & 100,0 \\
\hline \multirow{2}{*}{$\begin{array}{l}\text { Nenhuma das frases } \\
\text { explica o que é interesse } \\
\text { público }\end{array}$} & $\mathrm{N}$ & 3 & 3 & 4 & 0 & 10 \\
\hline & $\%$ & 30,0 & 30,0 & 40,0 & 0,0 & 100,0 \\
\hline \multirow{2}{*}{ Total } & $\mathrm{N}$ & 1070 & 691 & 505 & 7 & 2273 \\
\hline & $\%$ & 47,1 & 30,4 & 22,2 & 0,0 & 100,0 \\
\hline
\end{tabular}

Fonte: Centro de Referência do Interesse Público / Vox Populi, 2008

No teste do Qui-quadrado, constatamos uma alta associação entre as duas variáveis, sendo ela significativa na dimensão da amostra, revelando uma dependência entre concepções de interesse público e de corrupção. De uma forma muito superior à esperada, aquelas pessoas que possuem uma definição mais ampla de interesse público - "Todas as frases explicam do mesmo modo o que é interesse público" - tendem a considerar que as duas situações apresentadas são igualmente corruptas. 
Tabela 4

Teste do Qui-Quadrado

\begin{tabular}{|l|c|c|c|}
\hline & Valor & Graus de Liberdade & Valor P \\
\hline Pearson Chi-Square & 360,81 & 12 & 0,0 \\
\hline Likelihood Ratio & 308,985 & 12 & 0,0 \\
\hline Linear-by-Linear Association & 175,828 & 1 & 0,0 \\
\hline Casos válidos & 2273 & & \\
\hline
\end{tabular}

Fonte: Centro de Referência do Interesse Público / Vox Populi, 2008.

Os dados da Tabela 4 corroboram os dados e testes da Tabela 3.

A Tabela 5 procura compreender o modo como o brasileiro percebe a corrupção na dimensão das instituições. Foi pedido ao entrevistado que desse uma nota, variando em uma escala de 0 a 10, para a presença da corrupção em alguns ambientes institucionais, tanto públicos quanto privados. Nos extremos, a nota zero expõe nenhuma corrupção e a nota dez expõe muita corrupção. A tabela apresenta a análise das médias de notas atribuídas pelos entrevistados, expressando que a corrupção está mais presente nas instâncias representativas, em especial nas Câmaras de Vereadores, na Câmara dos Deputados, nas Prefeituras e no Senado Federal, e que tenham, de alguma forma, relação com o Estado. Importante notar que os ambientes institucionais que obtiveram indicadores médios acima da média das médias, à exceção da Polícia Federal, têm uma natureza pública e estatal. Por outro lado, os ambientes institucionais que obtiveram indicadores médios abaixo da média das médias têm uma natureza privada. Esse dado permite especular que o brasileiro exige excelência das instituições públicas e estatais, percebendo de forma um pouco mais branda a corrupção que é praticada no mundo privado, ligado às necessidades cotidianas ${ }^{9}$.

9 Testes estatísticos não mostraram significância na correlação entre os dados e indicadores sociais como educação, renda e gênero. 
Tabela 5

A presença da corrupção em ambientes institucionais

\begin{tabular}{|l|c|c|c|c|c|}
\hline \multicolumn{1}{|c|}{ Ambientes } & Média & $\begin{array}{c}\text { Desvio } \\
\text { padrão }\end{array}$ & $\begin{array}{c}\text { Limite } \\
\text { inferior }\end{array}$ & Limite superior & $\begin{array}{c}\text { Casos } \\
\text { válidos }\end{array}$ \\
\hline Câmara dos vereadores & 8,36 & 2,03 & 8,27 & 8,44 & $\mathrm{n}=2385$ \\
\hline Câmara dos Deputados & 8,34 & 1,95 & 8,26 & 8,41 & $\mathrm{n}=2397$ \\
\hline Prefeitura & 8,07 & 2,16 & 7,98 & 8,15 & $\mathrm{n}=2385$ \\
\hline Senado Federal & 8,02 & 2,12 & 7,93 & 8,10 & $\mathrm{n}=2366$ \\
\hline As pessoas mais ricas & 8,02 & 2,01 & 7,94 & 8,10 & $\mathrm{n}=2398$ \\
\hline Governo do Estado & 7,56 & 2,32 & 7,47 & 7,66 & $\mathrm{n}=2360$ \\
\hline Os empresários & 7,53 & 2,30 & 7,43 & 7,62 & $\mathrm{n}=2355$ \\
\hline Presidência da & 7,43 & 2,49 & 7,33 & 7,53 & $\mathrm{n}=2322$ \\
República & 7,42 & 2,44 & 7,32 & 7,52 & $\mathrm{n}=2369$ \\
\hline Polícia Militar & 7,37 & 2,47 & 7,27 & 7,47 & $\mathrm{n}=2359$ \\
\hline Polícia Civil & 7,36 & 2,38 & 7,26 & 7,46 & $\mathrm{n}=2331$ \\
\hline O Poder Judiciário & 7,15 & 2,54 & 7,05 & 7,26 & $\mathrm{n}=2313$ \\
\hline Clubes de Futebol & 6,88 & 2,29 & 6,79 & 6,97 & $\mathrm{n}=2372$ \\
\hline Os homens & 6,67 & 2,71 & 6,55 & 6,78 & $\mathrm{n}=2228$ \\
\hline Igrejas Evangélicas & 6,67 & 2,31 & 6,58 & 6,77 & $\mathrm{n}=2348$ \\
\hline O povo brasileiro & 6,64 & 2,72 & 6,53 & 6,75 & $\mathrm{n}=2299$ \\
\hline Polícia Federal & 6,59 & 2,23 & 6,50 & 6,68 & $\mathrm{n}=2370$ \\
\hline A classe média & 6,33 & 2,65 & 6,22 & 6,44 & $\mathrm{n}=2273$ \\
\hline A mídia & 6,32 & 2,47 & 6,21 & 6,42 & $\mathrm{n}=2262$ \\
\hline Movimentos Sociais & 5,84 & 2,66 & 5,72 & 5,95 & $\mathrm{n}=2131$ \\
\hline ONGs & 5,65 & 2,66 & 5,54 & 5,77 & $\mathrm{n}=2127$ \\
\hline Associação de Bairro & 5,57 & 2,80 & 5,46 & 5,69 & $\mathrm{n}=2106$ \\
\hline Igreja Católica & 5,42 & 2,50 & 5,32 & 5,53 & $\mathrm{n}=2223$ \\
\hline As pessoas mais jovens & 5,15 & 2,55 & 5,04 & 5,25 & $\mathrm{n}=2196$ \\
\hline As mulheres & 4,85 & 2,70 & 4,73 & 4,96 & $\mathrm{n}=2111$ \\
\hline As pessoas mais velhas & 4,86 & 4,92 & $\mathrm{n}=2016$ \\
\hline As pessoas mais pobres & 4,80 & 2,85 & 4,67 & 4,92 & $\mathrm{n}=2418$ \\
\hline Média das médias & 6,80 & 1,45 & 6,75 & 6,86 & \\
\hline
\end{tabular}

Fonte: Centro de Referência do Interesse Público / Vox Populi, 2008

$\mathrm{Na}$ Tabela 6, foi pedido aos entrevistados uma nota de zero a dez para determinados casos, sendo zero a representação de casos de nenhuma corrupção e dez para casos de muita corrupção. O objetivo foi medir a intensidade com que os entrevistados consideram determinadas situações como muito ou pouco corrompidas ou corruptoras. Os entrevistados consideraram os casos apresentados como de muita corrupção, com médias bastante altas, à exceção dos casos de subornar um funcionário público para tirar um documento mais rápidamente ou praticar grilagem de terras do governo. Existe, nesse sentido, um parâmetro moral, pressuposto de acordo com concepções normativas de certo e errado, em que a corrupção é condenável do ponto de vista dos valores da sociedade. Contudo, os 
dados da Tabela 7 revelam que os mesmos entrevistados concordam com situações em que a corrupção pode ser praticada.

Tabela 6

Médias da intensidade da corrupção em situações concretas

\begin{tabular}{|l|c|c|c|c|c|}
\hline \multicolumn{1}{|c|}{ Casos } & Média & $\begin{array}{c}\text { Desvio } \\
\text { padrão }\end{array}$ & $\begin{array}{c}\text { Limite } \\
\text { inferior }\end{array}$ & $\begin{array}{c}\text { Limite } \\
\text { superior }\end{array}$ & $\begin{array}{c}\text { Casos } \\
\text { Válidos }\end{array}$ \\
\hline $\begin{array}{l}\text { Um policial usar seu poder para tirar } \\
\text { vantagem ou dinheiro de alguém }\end{array}$ & 9,25 & 1,38 & 9,20 & 9,31 & $\mathrm{n}=2413$ \\
\hline $\begin{array}{l}\text { Um empresário financiar a campanha de } \\
\text { um político esperando receber algo em } \\
\text { troca }\end{array}$ & 9,12 & 1,47 & 9,06 & 9,18 & $\mathrm{n}=2408$ \\
\hline $\begin{array}{l}\text { Um político receber dinheiro para } \\
\text { favorecer uma empresa em uma } \\
\text { licitação }\end{array}$ & 9,08 & 1,61 & 9,01 & 9,14 & $\mathrm{n}=2397$ \\
\hline $\begin{array}{l}\text { Um promotor de justiça fazer "vista } \\
\text { grossa" aos erros cometidos por outro } \\
\text { promotor }\end{array}$ & 8,95 & 1,70 & 8,88 & 9,02 & $\mathrm{n}=2405$ \\
\hline $\begin{array}{l}\text { Um político financiar uma ONG, } \\
\text { esperando apoio em eleições }\end{array}$ & 8,75 & 1,82 & 8,68 & 8,83 & $\mathrm{n}=2383$ \\
\hline $\begin{array}{l}\text { Um funcionário público deixar de } \\
\text { denunciar as fraudes cometidas por seu } \\
\text { chefe }\end{array}$ & 8,67 & 1,87 & 8,60 & 8,75 & $\mathrm{n}=2409$ \\
\hline $\begin{array}{l}\text { Pagar um funcionário público para tirar } \\
\text { um documento que precisa mais rápido }\end{array}$ & 8,43 & 2,05 & 8,35 & 8,51 & $\mathrm{n}=2394$ \\
\hline $\begin{array}{l}\text { Uma pessoa (ou família) invadir terras } \\
\text { do governo e explorar essa terra } \\
\text { economicamente }\end{array}$ & 7,94 & 2,35 & 7,84 & 8,03 & $\mathrm{n}=2320$ \\
\hline MÉDIA DAS MÉDIAS & 8,76 & 1,31 & 8,70 & 8,81 & $\mathrm{n}=2418$ \\
\hline
\end{tabular}

Fonte: Centro de Referência do Interesse Público / Vox Populi, 2008.

A Tabela 7 mostra resultados obtidos quando os entrevistados foram questionados a respeito de algumas situações práticas que poderiam representar a corrupção. O objetivo desse questionamento era considerar antinomias possíveis entre normas morais e prática social, tendo em vista dados categóricos que perguntavam se o entrevistado concorda ou não com a situação exposta. O caráter subjetivo de todo survey, dessa forma, pode subestimar se, de fato, diante de uma situação prática, o indivíduo entraria ou não em um esquema de corrupção, por exemplo. Contudo, os dados mostram que é relativamente alto o percentual de pessoas que concordam com situações de corrupção e julgam que ela seja algo "natural" à política. Pelo conceito de prática de Bourdieu (2005), é importante compreender que essas representações espelham situações concretas relacionadas a um capital cultural acumulado na sociedade brasileira, definindo, dessa forma, os 
elementos da ação social. Assim, essas considerações a respeito da corrupção no Brasil carregam um sentido prático definido em torno de concepções culturais e um conhecimento social latente. Os dados da Tabela 7 mostram que, apesar de as pessoas concordarem com determinadas normas morais, como, por exemplo, o valor da honestidade, elas estão propensas a participar de esquemas de corrupção.

Tabela 7

Concepções a respeito da corrupção no Brasil (\%)

\begin{tabular}{|c|c|c|c|c|c|}
\hline Concepções & Concorda & $\begin{array}{l}\text { Não concorda } \\
\text { nem discorda }\end{array}$ & Discorda & NS/NR & Total \\
\hline $\begin{array}{l}\text { Em algumas situações, é bobagem a pessoa não entrar } \\
\text { em um esquema de corrupção, pois se ela não entrar, } \\
\text { outro entra. }\end{array}$ & 30 & 7 & 60 & 3 & 100 \\
\hline $\begin{array}{l}\text { Qualquer um pode ser corrompido, dependendo do } \\
\text { preço que for pago ou da pressão que for feita. }\end{array}$ & 39 & 7 & 51 & 3 & 100 \\
\hline $\begin{array}{l}\text { Corrupção e honestidade vêm de berço: ou a pessoa é } \\
\text { corrupta ou não é. }\end{array}$ & 55 & 9 & 34 & 2 & 100 \\
\hline $\begin{array}{l}\text { Se for para ajudar alguém muito pobre, muito } \\
\text { necessitado, não faz mal um pouco de corrupção. }\end{array}$ & 26 & 11 & 62 & 2 & 100 \\
\hline $\begin{array}{l}\text { Se você ficar sabendo de algum esquema de } \\
\text { corrupção, deve sempre denunciar às autoridades. }\end{array}$ & 73 & 11 & 13 & 2 & 100 \\
\hline $\begin{array}{l}\text { Algumas coisas podem ser um pouco erradas mas não } \\
\text { corruptas, como por exemplo sonegar algum imposto, } \\
\text { quando ele é caro demais. }\end{array}$ & 36 & 12 & 49 & 4 & 100 \\
\hline $\begin{array}{l}\text { Se as leis que existem fossem cumpridas e não } \\
\text { existisse tanta impunidade, a corrupção diminuiria. }\end{array}$ & 84 & 5 & 9 & 2 & 100 \\
\hline $\begin{array}{l}\text { O conceito de honestidade é relativo, depende da } \\
\text { situação. }\end{array}$ & 48 & 11 & 38 & 3 & 100 \\
\hline $\begin{array}{l}\text { Em qualquer situação, não interessa qual, existe } \\
\text { sempre chance da pessoa ser honesta. }\end{array}$ & 85 & 5 & 10 & 1 & 100 \\
\hline $\begin{array}{l}\text { Não tem jeito de fazer política sem um pouco de } \\
\text { corrupção. }\end{array}$ & 31 & 8 & 59 & 2 & 100 \\
\hline $\begin{array}{l}\text { Se for para proteger alguém de sua família, está certo } \\
\text { fazer alguma coisa um pouco corrupta. }\end{array}$ & 25 & 11 & 61 & 3 & 100 \\
\hline $\begin{array}{l}\text { Se estiver necessitada e um político oferecer benefícios } \\
\text { em troca do voto, não está errado a pessoa aceitar. }\end{array}$ & 26 & 10 & 62 & 2 & 100 \\
\hline $\begin{array}{l}\text { Dar um dinheiro para um guarda para escapar de uma } \\
\text { multa não chega a ser um ato corrupto. }\end{array}$ & 24 & 8 & 66 & 2 & 100 \\
\hline $\begin{array}{l}\text { Para diminuir a corrupção, estão faltando novas leis, } \\
\text { com penas maiores e mais duras. }\end{array}$ & 82 & 6 & 11 & 1 & 100 \\
\hline
\end{tabular}

Fonte: Centro de Referência do Interesse Público / Vox Populi, 2008. 
As concepções apresentadas na Tabela 7 mostram elementos plásticos e bastante flexíveis a respeito da corrupção. Mas por que poderíamos dizer que existe uma tolerância à corrupção no Brasil? Ao mesmo tempo em que os entrevistados consideram as ações descritas na Tabela 6 "muito corruptas", uma parte considerável deles concorda em entrar em um esquema de corrupção (30\%), admite que qualquer um pode ser corrompido, dependendo do preço (39\%), que a corrupção e a honestidade veem de berço (55\%), que a corrupção é válida para ajudar os mais pobres (26\%), que sonegar imposto é válido (36\%), que o conceito de honestidade é relativo (48\%), que não tem jeito de fazer política sem um pouco de corrupção (31\%), que a corrupção é válida para proteger alguém da família (25\%), que em casos de necessidade é correto vender o voto (26\%), que subornar um guarda não chega a ser um ato corruptor (24\%). A Tabela 7, por sua vez expõe concepções práticas comuns ao cotidiano e que envolvem o tema da corrupção. É notável que essas concepções práticas são passíveis de avaliação por parte do entrevistado, que o faz tomando perspectivas morais de correção da ação, isso é, se a ação descrita é correta ou não com base em deveres morais do cidadão. Nesse caso, contrastando com a Tabela 6 , percebemos a posição dúbia do entrevistado. Ele considera determinadas ações erradas, mas, diante de um cotidiano marcado por necessidades, ele tem uma propensão a tolerar certa corrupção. Não há consenso sobre as situações expostas na Tabela 7, porquanto as discordâncias são elevadas. Na maior parte das vezes, foram colocadas situações movidas por necessidades, como impostos, proteção da família, ajuda aos pobres, etc. É esse contexto de necessidades que contradiz a imoralidade descrita para a corrupção, criando um contexto de tolerância a esse tipo de prática.

O que os dados da Tabela 7 revelam, em contraposição à Tabela 6, é uma antinomia, existente no Brasil, entre normas morais e prática social. Ou seja, a corrupção não pode ser explicada pelo caráter do brasileiro, por sua cordialidade, malandragem ou esperteza, porque ele é capaz de absorver conteúdos substantivos da moralidade política, ao discordar de situações de corrupção. Os entrevistados consideram errado um político receber dinheiro para favorecer uma empresa em uma licitação, ou um empresário financiar campanhas esperando receber algo em troca. Porém, quando é para proteger a família, um pouco de corrupção é tolerável ou, se houver necessidade, é correto vender o próprio voto. Nesse caso, os entrevistados têm noção dos valores públicos, mas os juízos de necessidade corrompem, frente a uma tolerância da corrupção vista no outro, nunca em si mesmo. Existe uma disposição prática do brasileiro a entrar em esquemas de corrupção, que contrasta com sua configuração moral. Somos capazes de, 
consensualmente, concordar com determinados valores morais, mas toleramos certa corrupção porquanto ela esteja referida a um capital cultural que a torna cotidiana e latente, com uma natureza extremamente flexível, sendo aplicada a situações muito diferentes. É no intermédio dos juízos de valor e dos juízos de necessidade - como na Figura 1 - que a tolerância à corrupção opera.

A tolerância à corrupção não é um desvio de caráter do brasileiro, uma propensão e culto à imoralidade, nem mesmo uma situação de cordialidade, mas uma disposição prática nascida de uma cultura em que as preferências estão circunscritas a um contexto de necessidades, representando uma estratégia de sobrevivência que ocorre pela questão material. A tolerância à corrupção não é uma imoralidade do brasileiro, mas uma situação prática pertencente ao cotidiano das sociedades capitalistas. A confrontação entre excelência e cotidiano cria uma antinomia entre valores e prática, tornando a corrupção um tipo de estratégia de sobrevivência, mesmo em um contexto onde a moralidade existe. Isso implica que a corrupção represente um desafio à democratização brasileira, não no plano formal, mas no plano da cultura política. Não se pode dizer, portanto, que o brasileiro típico represente um caso de ausência de virtudes. As democracias não podem confiar apenas nas virtudes dos cidadãos, uma vez que é fundamental pensar a efetividade das leis. As virtudes são necessárias, mas não representam uma condição suficiente para manter o funcionamento da democracia. É necessário pensar, porém, no caso brasileiro, um processo de democratização no plano da sociabilidade e da cultura, tendo como horizonte uma democracia que não se resuma a seus ritos formais, mas que seja capaz de garantir a adesão do cidadão comum às instituições democráticas, tendo em vista a efetividade da lei e mecanismos democráticos de controle da corrupção. O que poderia tornar a corrupção no Brasil endêmica seria a possibilidade dos valores públicos degenerarem.

\section{Considerações finais}

A pesquisa apresentada carece de um sentido comparativo com experiências internacionais, bem como de uma série histórica que permita inferências mais conclusivas. Contudo, os dados apontam para o fato de que a democratização brasileira ainda carece de efetivação de princípios e valores fundamentais que alicercem uma cultura política democrática. Apesar de avanços nesse caminho, como demonstram Moisés e Carneiro (2008), ainda persistem posições céticas e cínicas entre os cidadãos em relação às instituições formais. O resultado é a constatação de uma síndrome de desconfiança e indiferença. 
A posição contraditória do cidadão comum em relação à corrupção acarreta esse contexto de tolerância, fazendo com que indivíduos tomem atitudes em que preferem aderir a esquemas de corrupção e afirmar que as pessoas têm um preço a seguirem a lei. Os dados mostram, entretanto, que esse mesmo cidadão comum é capaz de reconhecer valores morais fundamentais e, consensualmente, reconhecer que esses valores são importantes na dimensão da sociabilidade e da política. Isso ocorre, do ponto de vista normativo, pela cisão entre valores e necessidades, configurando juízos muitas vezes assentados em uma visão agonística da vida, sem perceber a necessidade de concepções mais amplas de vida republicana. Essa posição da cidadania, tendo em vista o problema da corrupção, tem por consequência reduzir a accountability do sistema político, ao enfraquecer o sistema de fiscalização em relação às atividades das instituições políticas. Falta, nesse sentido, uma noção mais ampla de público a partir da qual se deve pensar o tema da corrupção não apenas no plano das instituições formais da democracia, mas na ideia de vida democrática.

No que diz respeito à corrupção, constata-se que não basta uma mudança do aparato formal ou da máquina administrativa do Estado propriamente dita, mas reforçar os elementos de uma cultura política democrática que tenha no cidadão comum, feito de interesses, sentimentos e razão, o centro de especulação teórica e prática para uma democratização informal da democracia brasileira. Os avanços das reformas da máquina pública, nas duas últimas décadas, são inegáveis, com o reforço da transparência. Contudo, falta, à democracia brasileira, um senso maior de publicidade, pelo qual a transparência esteja referida a uma ativação da cidadania, à accountability e à participação, sem os quais os esforços de combate e controle da corrupção ficarão emperrados em meio a uma cultura política tolerante às delinquências do homem público.

\section{Referências Bibliográficas}

ABRAMO, C. W. "Percepções pantanosas. A dificuldade de medir a corrupção". Novos Estudos - CEBRAP, n 73, 2005.

ANECHIARICO, F. e JACOBS, J. The persuit of absolute integrity: How corruption control makes government ineffective. Chicago: The University of Chicago Press, 1996. 
BANFIELD, E. The moral basis of backward society. Glencoe: Free Press; Chicago: The University of Chicago, Research Center in Economic Development and Cultural Change, 1958.

BONFIM, M. A América Latina. Coleção Intérpretes do Brasil. Rio de Janeiro: Nova Aguilar, v. II, 2002.

Razões práticas. Sobre a Teoria da Ação. Campinas: Papirus, 1996.

BOURDIEU, P. O poder simbólico. Rio de Janeiro: Bertrand Brasil, 2005.

CAMPANTE, R. G. "O patrimonialismo em Faoro e Weber e a sociologia brasileira". Dados - Revista de Ciências Sociais, v.46, n¹, 2003.

CÂNDIDO, A. O significado de Raízes do Brasil. In: HOLLANDA, S. B. de. Raízes do Brasil. São Paulo: Companhia das Letras, 1995.

CARVALHO, J. M. de. "Mandonismo, coronelismo, clientelismo. Uma discussão conceitual". Dados - Revista de Ciências Sociais, v. 40, n² 2, 1997.

Passado, presente e futuro da corrupção brasileira, In: AVRITZER, L., et al. (orgs.). Corrupção: ensaios e crítica. Belo Horizonte: Editora da UFMG, 2008.

DA MATTA, R. Carnavais, malandros e heróis. Uma sociologia do dilema brasileiro. Rio de Janeiro: Jorge Zahar Editor, 1980.

DURKHEIM, E. As regras do método sociológico. São Paulo: Martins Fontes, 2003.

FAORO, R. Os donos do poder. Formação do patronato político brasileiro. São Paulo: Globo, 2000.

FILGUEIRAS, F. "A corrupção na política: perspectivas teóricas e metodológicas". Cadernos Cedes, IUPERJ, n 5, 2006. 
$2008 a$

Corrupção, democracia e legitimidade. Belo Horizonte: Editora da UFMG,

Marcos teóricos para o estudo da corrupção. In: AVRITZER, L., BIGNOTTO, N., et al. Corrupção: ensaios e crítica. Belo Horizonte: Editora UFMG, 2008b.

HABERMAS, J. Correção versus verdade. O sentido da validade deontológica de juízos e normas morais. In: Verdade e justificação. Ensaios Filosóficos. São Paulo: Loyola, 2004.

HEIDENHEIMER, A. Perspectives on the perception of corruption. In: HEIDENHEIMER, A e JOHNSTON, M. (orgs.). Political corruption. Concepts and contexts. New Brunswick: Transactions Publishers, 2001.

HOLLANDA, S. B.e de. Raízes do Brasil. São Paulo: Companhia das Letras, 1995.

HUNTINGTON, S. P. A ordem política nas sociedades em mudança. São Paulo: EDUSP, Rio de Janeiro: Forense-Universitária, 1975.

JOHNSTON, M. Syndromes of corruption. Wealth, power, and democracy. Cambridge: Cambridge University Press, 2005.

KRUGER, A. O. "The political economy of rent-seeking", American Economic Review, $n^{\circ} 64,1974$.

LEFF, N. H. "Economic development through bureaucratic corruption". American Behavioral Scientist, v. 8, n 3, 1964.

LIPSET, S. M. e LENZ, G. S. Corrupção, cultura e mercados, In: HUNTINGTON, S. e HARRINSON, L. (orgs.). A cultura importa: Os valores que definem o progresso humano. Rio de Janeiro: Record, 2002.

MERTON, R. K. Sociologia: teoria e estrutura. São Paulo: Mestre Jou, 1970. 
MOISÉS, J. A. e CARNEIRO, G. P. "Democracia, desconfiança política e insatisfação com o regime: o caso do Brasil". Opinião Pública, v. 14, n 1, 2008.

ROSE-ACKERMAN, S. Corruption and government. Causes, consequences and reform. Cambridge: Cambridge University Press, 1999.

SCHWARTZMAN, S. Bases do autoritarismo brasileiro. Rio de Janeiro: Campus, 1982.

SOUZA, J. "A sociologia dual de Roberto Da Matta: descobrindo nossos mistérios ou sistematizando nossos auto-enganos?". Revista Brasileira de Ciências Sociais, v. 16, $n^{\circ}$ 45, 2001.

SCOTT, J. "Corruption, machine politics, and political change". American Political Science Review, v. 63, nº 4, 1969.

TAYLOR, C. Sources of the self. Harvard: Harvard University Press, 1992.

TULLOCK, G. "The welfare costs of tariffs, monopolies, and theft". Western Economic Journal, n 5, 1967.

VIANNA, L. W. "Weber e a interpretação do Brasil". Novos Estudos, CEBRAP, n 53, 1999.

WARREN, M. "What does corruption mean in a democracy?". American Political Science Review, v. 48, $n^{\circ}$ 2, 2004.

Fernando Filgueiras - fernandofilgueira@hotmail.com

Recebido para publicação em março de 2009.

Aprovado para publicação em julho de 2009. 